\title{
Editors' Foreword
}

\section{Paul Hedges}

\section{NANyAng TeChNological University}

\author{
ispmhedges@ntu.edu.sg
}

This edition provides a special issue on Buddhist perspectives towards religious diversity, which includes papers from a range of global contexts and differing traditions. This is something which is important as so much of the literature writes out of Western contexts, or simply focuses upon the disputes amongst the three so-called Abrahamic cousins of Judaism, Christianity, and Islam. Indeed, often when Buddhism is invoked we hear the age-worn trope of asking, "What is the Buddhist perspective on ... X." This reinforces a reification of that tradition which ignores the internal diversity within it. As such, by referencing aspects of, or examples from, Theravada, Mahayana, and Vajrayana Buddhism we get a much richer picture. In particular, also raising Asian perspectives and theoretical bases provides an area where we meet a greater range of viewpoints than is typically found. At the least, it is a wider amount of food for thought to scholars within the disciplines and fields that have an interest in interreligious relations, theological perspectives on diversity, and the dynamic social interaction between traditions. These articles are selected from a wider group of essays that will appear in a forthcoming book from Equinox with the title Buddhist Responses to Religious Diversity: Theravāda and Tibetan Perspectives and edited by Douglas Duckworth, Abraham Vélez de Cea, and Elizabeth J. Harris. In this journal issue we have provided an additional two articles that are not included in the book.

The special issue articles include papers by Abraham Vélez de Cea who, in "The Dalai Lama and Religious Diversity," talks about one of the most talked about figures in the global religious world. He provides an overview of his attitudes in a more systematised fashion than typically found in the Dalai Lama's own writings, but also extends into a critical analysis of this. Elizabeth Harris, meanwhile offers reflections on the problems of Sri Lanka in her paper "Buddhism and the Religious Other: Twenty-First Century Dambulla and the presence of Buddhist Exclusivism in Sri Lanka." She focuses upon the discourse in creating a particular site, Dambulla, but raising wider theoretical questions about how people construct meaning in the world. Rachel Pang's paper "The Contemporary Tibetan Buddhism Rimé Response 
to Religious Diversity," looks at the notion of an inclusive, or "ecumenical" response to diversity using the concept of "Rimé" within Tibetan Buddhist communities in various places, and how this relates to contemporary trends. A more philosophical turn is taken by Douglas Duckworth who uses the notion of the tetralemma found within the work of the Mahayana thinker Nāgārjuna, in "Buddhism and Beyond: The Question of Pluralism." This will particularly raise the distinction between ultimate and proximate levels of truth found in Buddhist thought and how this may be fruitful for reflecting on these issues. Next, Asanga Tilakaratne raises the question of how religious diversity may be thought about from a Buddhist context, importantly raising the issue that this is often today a response to Christian discourse in his paper "Religious Diversity and Dialogue: Some Buddhist Reflections." He addressed the typology of exclusivisms, inclusivisms, and pluralisms looking at how this may relate to dialogue and with a particular reference to Sri Lanka. Finally, Rita Gross in "Finding the Right Questions about Religious Diversity: What Buddhist Could Contribute to Discussions of Religious Diversity" seeks what may be said to be a Western Buddhist standpoint on diversity that discusses "non-conceptuality" amongst other issues to argue for a Buddhist pluralist stance that does not seek to universalise its own stance.

The first of the other two papers is by Oddbjørn Leirvik, who writes on "Islamic humanism or humanistic Islam?" His paper provides an analysis and synthesis of various Muslim scholars who have argued for an Islamic humanism with a particular focus on Norwegian sources, providing another not often known contextual study. The other paper is by Mohamad Abdun Nasir who in his paper "Conflict, Peace, and Religious Festivals: Muslim-Hindu-Christian Relations on the Eastern Indonesian Island of Lombok."discusses how conflict and peace is negotiated by Muslims, Hindus and Christians in the Indonesian island of Lombok. Again, this provides us with a wider global context to help us see a wider set of issues, and also it gives us a focus on the co-performance of rituals and festivals amongst those communities, raising another set of much discussed questions in current debates. 